\title{
ANALISIS KADAR ALKOHOL PRODUK KOMBUCHA DAUN PERMOT (Passiflora foetida L.) ASAL MAKASSAR SULAWESI SELATAN SECARA KROMATOGRAFI GAS
}

\author{
Herwin, Rachmat Kosman, Fitriani \\ Fakultas Farmasi Universitas Muslim Indonesia \\ Email : herwinfarmasi@gmail.com
}

\begin{abstract}
Preliminary research permot leaf (Passiflora foetida L.) used Acetobacter xylinum bacterial culture and Sacharomyces cerevisiae yeast fermentation in determined the alcohol content of kombucha with the purpose of determined the alcohol content of kombucha products permot leaf (Passiflora foetida L.) from Makassar in South Sulawesi gas chromatography. Based on result of research fermentation of kombucha product from permot leaf by add glucose 100 gram and inoculum kombucha $10 \%$ obtaired content by gas chromatography as big as $0,0627292 \%$.
\end{abstract}

Keyword : Permot leaf, kombucha, alcohol, gas chromatography

\section{PENDAHULUAN}

Permot (Passiflora foetida L.) merupakan tanaman yang termasuk dalam jenis tanaman gulma dan juga tanaman perdu. Namun memiliki bunga yang begitu indah mirip dengan bunga tanaman markisah. Permot adalah tanaman herba yang berasal dari Amerika tropis yang dapat ditemukan pada ketinggian 1-1000 m dpl, tumbuhan yang hidupnya di tempat-tempat liar atau terbuka yang mendapat cahaya matahari, seperti di semak-semak, tanah lapang yang terlantar, atau merambat di pagar yang berkhasiat sebagai obat batuk, radang kelenjar, insomnia, darah tinggi, bengkak, kencing berlemak, dan borok.

Dari beberapa jenis obat tradisional yang banyak digunakan di masyarakat, salah satunya adalah teh kombucha. Menurut beberapa penelitian dan pengalaman beberapa orang yang menggunakan teh ini terbukti berkhasiat dan menyembuhkan beberapa penyakit, diantaranya untuk kanker terutama pada stadium awal, antiinflamasi, melancarkan pencernaan, menetralisir asam urat sehingga bermanfaat gout, rematik, arthritis dan juga sebagai peluruh batu ginjal. Kombucha, atau dikenal masyarakat Indonesia sebagai 
jamur teh, atau jamur dipo, adalah fermentasi teh menggunakan campuran kultur bakteri dan khamir sehingga diperoleh citarasa asam dan terbentuk lapisan nata. Daun Permot (Passiflora foetida L.) merupakan salah satu bahan yang digunakan untuk membuat produk kombucha dan dikonsumsi tanpa mengetahui seberapa besar kandungan alkohol di dalam kombucha daun permot tersebut. Pada penelitian-penelitian sebelumnya telah dilakukan beberapa pengujian produk kombucha daun permot yaitu pengujian organoleptik, pengukuran nilai $\mathrm{pH}$, pengujian kadar total asam, uji mikrobiologis dan aktivitas antimikroba.

Menurut ijtihad fatwa Majelis Ulama' Indonesia (MUI) ketentuan kadar alkohol dalam minuman yang diperbolehkan untuk dikonsumsi adalah $<1 \%$.

Hal inilah yang melatar belakangi dilakukan penelitian tentang analisis kadar alkohol produk kombucha daun Permot (Passiflora foetida L.) asal Makassar Sulawesi Selatan secara Kromatografi Gas.

\section{METODE PENELITIAN}

\section{Waktu dan Tempat Penelitian}

Penelitian ini dilaksanakan pada bulan Desember 2012 sampai selesai di Laboratorium Mikrobiologi Fakultas Farmasi Universitas Muslim Indonesia dan dianalisis dengan kromatografi gas di Laboratorium Teknik Kimia Politeknik Negeri Ujung Pandang.

\section{Alat dan bahan Penelitian}

Alat-alat yang dipakai adalah Autoklaf (Smic Model YX-280 B), Erlenmeyer $1000 \mathrm{ml}$ (Iwaki pyrex), gelas kimia $1000 \mathrm{ml}$ (Iwaki Pyrex), gelas ukur $100 \mathrm{ml}$ (Iwaki pyrex), Kromatografi Gas (SHIMIDZU 130.000), Laminar air flow, Seperangkat alat destilasi dan timbangan analitik (Chyo).

Bahan-bahan yang digunakan adalah air suling, etanol 99,8\%, glukosa, daun permot (Passiflora foetida L.), kultur kombucha.

\section{Prosedur Penelitian}

\section{Strelisasi Alat dan Bahan}

Alat-alat yang digunakan dicuci bersih dengan air bersih kemudian dikeringkan. Untuk gelas ukur dan kain saring disterilkan di autoklaf dengan suhu $121^{\circ} \mathrm{C}$ selama 15 menit dan botol fermentasi dan batang pengaduk disterilkan di oven dengan suhu $180^{\circ} \mathrm{C}$ selama 2 jam.

\section{Penyiapan Sampel Penelitian}

\section{Pengolahan Sampel}

Daun permot dipetik pada pukul 10.00 wita dan disortasi untuk menghilangkan kotoran yang melekat 
pada daun permot. Daun permot dikeringkan dengan cara dianginanginkan untuk mengurangi kadar air yang terdapat dalam daun permot kemudian dihaluskan dengan tujuan untuk memudahkan dalam pembuatan teh kombucha.

\section{Penyiapan Kultur Kombucha}

Ditimbang $15 \mathrm{~g}$ teh hijau lalu dimasukkan kedalam panci infuse dengan air secukupnya dan dipanaskan di atas tangas air selama 15 menit terhitung mulai suhu mencapai $90^{\circ} \mathrm{C}$ sambil sesekali diaduk. Disaring kedalam wadah kaca, setelah disaring dicukupkan volumenya dengan air matang melalui ampas hingga $100 \mathrm{ml}$. infuse teh hijau ditambahkan gula pasir 10\% kemudian ditambahkan air matang hingga 1000 $\mathrm{ml}$ lalu diaduk sampai gula benarbenar larut dan didinginkan pada suhu kamar sampai suhunya kurang lebih $35^{\circ} \mathrm{C}$. lembaran jamur kombucha dimasukkan kedalam toples yang berisi infus teh, kemudian ditutup dengan kain kasa steril yang rapat dan diikat lalu didiamkan. Difermentasi hingga terbentuk lembaran jamur kombucha yang baru.

\section{Pembuatan Kombucha}

Rebus satu liter air hingga mendidih dalam wadah stainless steel atau panci. Kemudian tuangkan 10 gram teh dari daun permot kedalamnya. Biarkan beberapa menit (sekitar 15 menit) hingga teh melarut. Pisahkan ekstrak teh dengan ampas teh dengan cara disaring menggunakan kain saring. Selagi air masih panas, lalu tambahkan gula sebanyak 100 gram aduk hingga gula melarut sempurna. Biarkan suhu larutan teh manis turun hingga mencapai suhu ruangan (sekitar 25 $27^{\circ} \mathrm{C}$ ). Masukkan larutan teh tersebut kedalam toples kaca Kemudian masukkan bibit kombucha sebanyak $10 \%$ dan ditutup dengan menggunakan kain kasa. Dibiarkan pada suhu fermentasi selama 5 - 12 hari. Lapisan kombucha diangkat kemudian dicuci dengan air bersih. Hasil fermentasi selama 12 hari dimasukkan dalam botol kemasan kemudian disterilkan.

\section{Pengujian Sediaan Kombucha Permot \\ Proses destilasi}

Hasil fermentasi kombucha daun permot (Passiflora foetida L.), kemudian filtratnya didestilasi. Hasil destilasi dianalisis menggunakan kromatografi gas.

\section{Metode Analisis}

\section{Analisis kualitatif dengan kromatografi gas}


Analisis kualitatif dilakukan dengan membandingkan waktu retensi alkohol hasil fermentasi teh kombucha permot (Passiflora foetida L.) dengan alkohol murni (etanol 99,8 \%) sebagai parameter baku.

\section{Analisis kuantitatif dengan kromatografi gas}

Sampel disuntikkan kedalam kolom yang merupakan pemisahan sesungguhnya komponen cuplikan dengan menaikkan suhu pemanas

\section{HASIL PENELITIAN}

Grafik hasil analisis kadar alkohol kombucha dari daun permot (Passiflora foetida L.) pada konsentrasi $10 \%$ secara kromatografi gas.

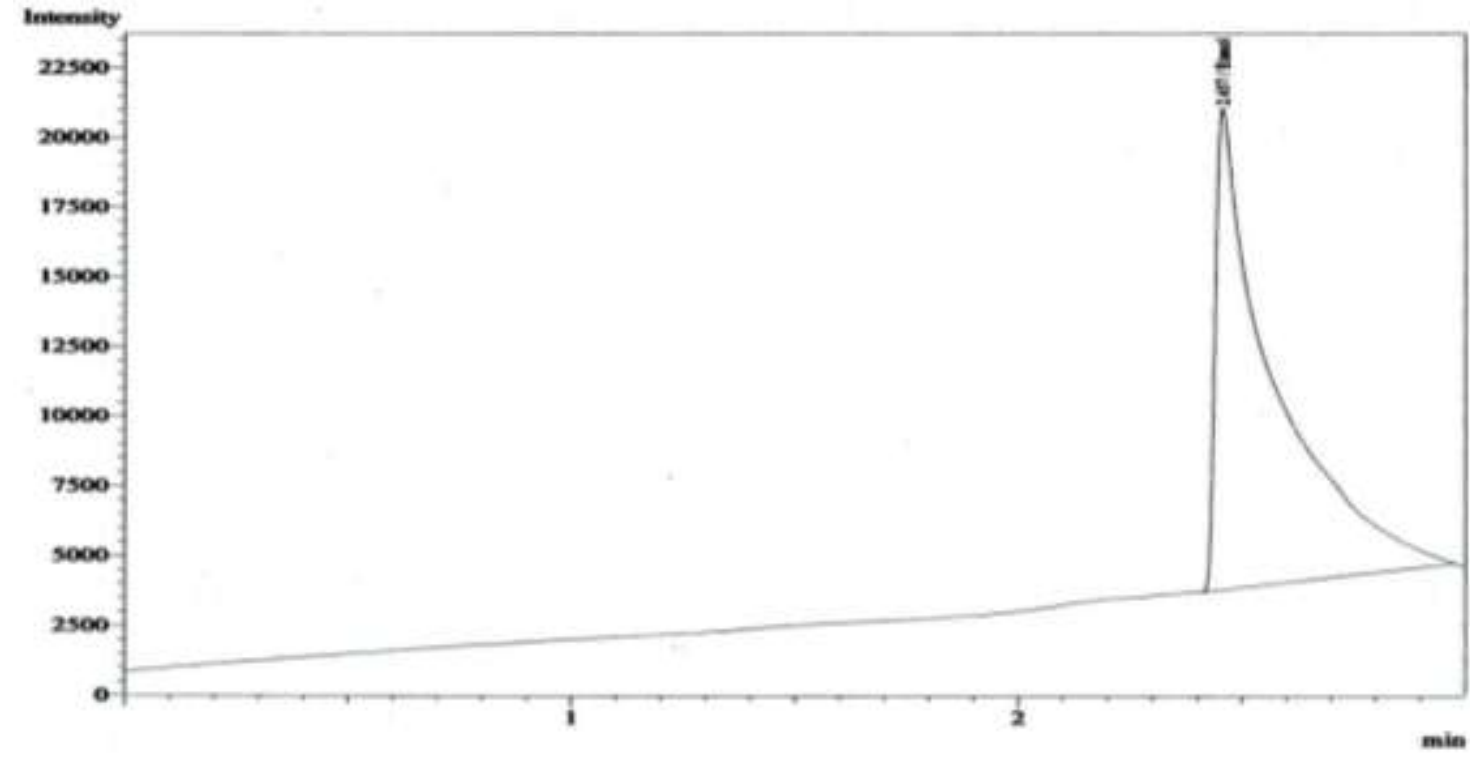

Tabel 1. Tabel hasil analisis kadar alkohol kombucha dari daun permo (Passiflora foetida L.) pada konsentrasi 10\% secara kromatografi gas

\begin{tabular}{ccccc}
\multicolumn{5}{c}{ foetida L.) pada konsentrasi 10\% secara kromatografi gas } \\
\hline Peak & Ret.Time & Area & Height & Name \\
\hline 1 & 2.457 & 157621 & 17221 & Etanol \\
\hline Total & & 157621 & 17221 & \\
\hline
\end{tabular}
cuplikan. Cuplikan dibawah oleh gas pembawa yang biasa digunakan ialah Penyangga padat menyediakan permukaan lembam yang luas dan seragam, tempat penyerapan fase cair. Detektor menunjukkan adanya komponen dalam eluen dan mengukur kuantitasnya, selanjutnya gaftar carik merekam hasil yang permanen. hydrogen, helium dan nitrogen. 


\section{PEMBAHASAN}

Kombucha atau dikenal masyarakat Indonesia sebagai jamur teh, atau jamur dipo, adalah produk minuman tradisional hasil fermentasi larutan teh dan gula dengan menggunakan campuran kultur bakteri dan khamir yang difermentasi selama 5 - 12 hari sehingga diperoleh citarasa asam dan terbentuk lapisan nata secara fermentasi.

Fermentasi pada awalnya hanya menunjukkan pada suatu peristiwa alami pada pembuatan anggur yang menghasilkan buih (ferment berarti buih). Fermentasi merupakan perubahan kimiawi secara okisdatif dari mikroorganisme dalam substrat dengan hasil pemecahannya berupa senyawa-senyawa yang lebih kompleks serta terjadi perubahan gula menjadi alkohol yang melibatkan kerja enzim (Sudarmadji, 1987).

Proses fermentasi kombucha terjadi simbiosis antara Acetobacter xylinum dan Saccharomycs serevisiae. Simbiosis ini menghasilkan zat asam dan alkohol yang menghalangi pertumbuhan mikroorganisme asing yang tidak berasal dari jamur kombucha (Blanc, 1996). Zat asam terbentuk karena adanya aktivitas mikroba yang ada di dalamnya secara terus menerus sampai zat gula di dalamnya habis. Selain zat asam, fermentasi ini juga menghasilkan polisakarida (selulosa).

Selama proses fermentasi glukosa berfungsi sebagai sumber karbon yang akan menstimulasi pertumbuhan Acetobacter xylinum sehingga mempercepat proses pembentukan selulosa. Persentasi glukosa dalam medium fermentasi kombucha permot dapat meningkatkan jumlah selulosa yang terbentuk. Semakin tinggi jumlah selulosa maka akan menyebabkan ketebalan nata semakin meningkat (Williems dan Wimpeny, 1977).

Analisis sampel dilakukan dengan alat kromatografi gas yang diinjeksikan kedalam injector dari kromatografi gas sehingga menghasilkan suatu kromatogram dengan waktu retensi dan luas puncak alkohol. Dari data tersebut dapat dihitung kadar alkohol dengan membandingkan luas puncak alkohol dalam sampel dengan luas puncak alkohol standar.

Hasil penelitian menunjukkan bahwa kadar alkohol produk kombucha daun Permot (Passiflora foetida L.) yang telah dianalisis dengan kromatografi gas adalah 0,0627292 \%. Dari hasil penelitian ini jika dibandingkan dengan literatur 
etanol dalam kombucha besarnya sekitar 0,5 - $1 \%$ dan berdasarkan kesepakatan MUI minuman beralkohol yang telah disepakati kadar etanolnya $<1 \%$ maka produk memenuhi persyaratan sebagai minuman hasil fermentasi.

\section{KESIMPULAN}

Berdasarkan hasil penelitian
yang dilakukan maka diperoleh
kesimpulan yaitu kadar alkohol yang
didapatkan dari produk kombucha
daun Permot (Passiflora foetida L.)
sebesar $0,0627292 \%$.

\section{DAFTAR PUSTAKA}

Bernasconi, G., 1995, Teknologi Kimia 2, Cetakan pertama Terjemahan Oleh Lienda Handojo M, Pradaya Paramita, Jakarta.

Bonelli, E.J.,Mc. Nasir, H.M., 1986, Dasar Kromatografi Gas, Terjemahan Oleh Kosasih Padwawinata. ITB, Bandung.

Cronquist, A., 1981, An Integrated System of Classification of Flowring Plants, Columbia University Press. New York

Dalimartha, S., 2008, Atlas Tumbuhan Obat Indonesia, Jilid 3, Puspa Swara. Jakarta

Didinkaem, 2006, Menggugat Status Halal Obat Beralkohol. http://www.halalguide.info/conte nt/view/553/38/ diakses 23 Januari 2013.
Ditjen POM, 1979, Farmakope Indonesia, Edisi Ketiga, Depkes RI, Jakarta.

Frank, G., W., 1995, Kombucha Healthy Beverage and Natural Remedy from the Far East, Terjemahan oleh Hendra Saputra, Pekanbaru.

Frank, G., W., 2012, Kombucha Healthy Beverage and Natural Remedy from the Far East, (kombu.de/anl-ind).

Garrity, M.G., 2004, Taxonomic Outline of the Prolcargotes Bergeys Marvel of Systemic Bacteriology. Second Edition. New York

Gumbira, E.S., 1987, Bioindustri Penerapan Teknologi Fermentasi, Mediyatma Saraya Perkasa, Jakarta.

Gunter, R.J., Bobbit J.M., Scwaring, A.E., $1991 . \quad$ Pengantar Kromatografi. Edisi Kedua. Diterjemahkan Oleh Kosasih Padmawinata. ITB, Bandung.

Hidayat, N., 2006, Mikrobiologi Industri, Penerbit: Andi. Yogyakarta

Kroschwitz, I.J., Winoker, M., 1990, Chemistry, General, Organic And Biological, Second Edition ML, Grew Hill Publishing Company.

Monick, A.J., 1968. Alkohol Their Chemistry Properties And Manufactures, Reirhold Book Co., New York, Amsterdam, London.

Muchtadi, T.,R., 2010, Teknologi Proses Pengolahan Pangan, Alfabeta. Bandung 
Analisis Kadar Alkohol Produk Kombucha Daun Permot Secara Kromatografi Gas

Naland, H., 2004, Kombucha Minuman Nikmat Yang Menyehatkan, Herba, Agromedia Pustaka, Jakarta

Naland, H., 2008, Kombucha Teh dengan Seribu khasiat, Agromedia Pustaka. Jakarta.
Respati, 1986, Pengantar Kimia Organik, Jilid I, Aksara Baru, Jakarta.

Samroni, 2007, Cara Praktis Membuat Nata de Coco, Sinar Cemerlang Abadi, Jakarta.

Yuniarti T., 2008, Ensiklopedia Tanaman Obat Tradisional, Media Pressindo, Yogyakarta 